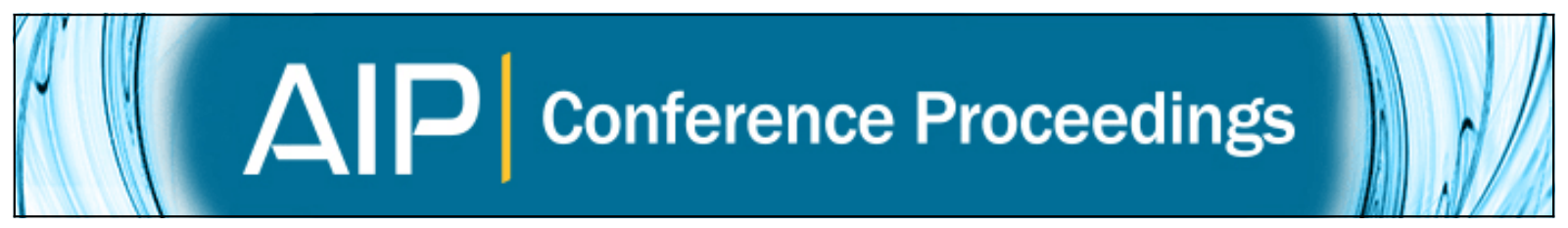

\title{
DSC and Raman studies of silver borotellurite glasses
}

Amandeep Kaur, Atul Khanna, and Fernando Gonzàlez

Citation: AIP Conference Proceedings 1731, 070036 (2016); doi: 10.1063/1.4947868

View online: http://dx.doi.org/10.1063/1.4947868

View Table of Contents: http://scitation.aip.org/content/aip/proceeding/aipcp/1731?ver=pdfcov

Published by the AIP Publishing

Articles you may be interested in

The study of interaction between graphene and metals by Raman spectroscopy

J. Appl. Phys. 109, 07 C501 (2011); 10.1063/1.3536670

Fluorescent glass embedded silver nanoclusters: An optical study

J. Appl. Phys. 103, 114313 (2008); 10.1063/1.2936879

Laser direct write of silver nanoparticles from solution onto glass substrates for surface-enhanced Raman spectroscopy

Appl. Phys. Lett. 91, 023107 (2007); 10.1063/1.2753090

Surface enhanced Raman scattering of $p$-aminothiophenol self-assembled monolayers in sandwich structure fabricated on glass

J. Chem. Phys. 124, 074709 (2006); 10.1063/1.2172591

Study of Glass Transition Temperatures in Sugar Mixtures by DSC

AIP Conf. Proc. 708, 697 (2004); 10.1063/1.1764267 


\title{
DSC and Raman Studies of Silver Borotellurite Glasses
}

\author{
Amandeep Kaur ${ }^{1}$, Atul Khanna ${ }^{1 *}$, Fernando Gonzàlez ${ }^{2}$ \\ ${ }^{1}$ Sensors and Glass Physics Laboratory, Department of Physics, \\ Guru Nanak Dev University, Amritsar-143005, Punjab, India \\ ${ }^{2}$ Department of Chemistry and Process \& Recourse Engineering, \\ University of Cantabria, Santander-39005, Spain \\ *E-mail: atul.phy@gndu.ac.in
}

\begin{abstract}
Silver borotellurite glasses of composition: $\mathrm{xAg}_{2} \mathrm{O}-\mathrm{yB}_{2} \mathrm{O}_{3}-(100-\mathrm{x}-\mathrm{y}) \mathrm{TeO}_{2}(\mathrm{x}=20-\mathrm{mol} \%, \mathrm{y}=0,10,20$ and 30 mol\%) were prepared and characterized by density, X-ray diffraction (XRD), differential scanning calorimetry, and Raman spectroscopy. XRD confirmed the amorphous structure of all samples. Density of glasses decreases while the glass transition temperature increases with increase in $\mathrm{B}_{2} \mathrm{O}_{3}$ content from 10 to 30-mol\%. Raman study shows that coordination number of Te with oxygen decreases steadily from 3.42 to 3.18 on adding $\mathrm{B}_{2} \mathrm{O}_{3}$ due to the transformation of $\mathrm{TeO}_{4}$ into $\mathrm{TeO}_{3}$ units.
\end{abstract}

Keywords: Borotellurite glasses, X-ray Diffraction, Differential Scanning Calorimetry, Raman spectroscopy. PACS: 64.70.kj, 61.05.cp, 65.60.+a, 33.20.Fb.

\section{INTRODUCTION}

Oxide glasses containing metal oxides have been studied for their interesting optical and electrical properties $[1,2]$. Tellurite glasses have several useful properties like high refractive index, high glass forming ability, low melting points, good chemical durability, low phonon maxima and non-hygroscopic nature. These glasses have high non-linear refractive indices due to lone electron pair of $\mathrm{Te}^{4+}$ ions [3-6]. Tellurium oxide is a conditional glass former; pure tellurite glass can be formed at very high quenching rates of $\sim 10^{5} \mathrm{~K} / \mathrm{s}$, it has Te-O coordination number, $\mathrm{N}_{\mathrm{Te}-\mathrm{O}}=3.69$ [7]. On incorporating metal oxides, Te-O coordination and glass properties get modified.

In tellurite glasses, the basic structural units are $\mathrm{TeO}_{4}$ trigonal bipyramids (tbp) and $\mathrm{TeO}_{3}$ trigonal pyramid (tp) [8]. The addition of metal oxides in tellurite glass causes breakage of Te-O-Te linkages, thereby resulting in systematic conversions of $\mathrm{TeO}_{4}$ into $\mathrm{TeO}_{3}$ structural units that contain doubly bonded terminal oxygens i.e. $\mathrm{Te}=\mathrm{O}$ bonds $[5,7]$.

Silver oxide acts as a modifier in the tellurite glass network and enhances the electrical conductivity of tellurite glasses. $\mathrm{B}_{2} \mathrm{O}_{3}$ is the best glass former and its addition in silver tellurite glasses modifies the glass network through the conversion of $\mathrm{TeO}_{4}$ into $\mathrm{TeO}_{3}$ [9]. The aim of this work is to study the thermal properties and short-range structural properties of silver borotellurite glasses by Differential Scanning Calorimetry (DSC) and Raman spectroscopy.

\section{EXPERIMENTAL}

Silver borotellurite glasses having composition: $\mathrm{xAg}_{2} \mathrm{O}-\mathrm{yB}_{2} \mathrm{O}_{3}-(100-\mathrm{x}-\mathrm{y}) \mathrm{TeO}_{2}(\mathrm{x}=20-\mathrm{mol} \%, \mathrm{y}=0,10$, 20 and $30-\mathrm{mol}^{\%}$ ) were prepared using $\mathrm{TeO}_{2}$ (Aldrich 99\%), $\mathrm{AgNO}_{3}$ (Qualigens 99.8\%) and $\mathrm{H}_{3} \mathrm{BO}_{3}$ (Aldrich $99.9 \%$ ) by splat quenching technique. Appropriate amounts of chemicals were weighed, mixed together and put in a $\mathrm{Pt}$ crucible. The batch mixture was sintered at $250^{\circ} \mathrm{C}$ for $24 \mathrm{~h}$ in an electric furnace. The furnace temperature was then slowly raised to $950^{\circ} \mathrm{C}$ and the melt was kept at this temperature for $30 \mathrm{~min}$, subsequently a small quantity of the melt was poured and pressed between two heavy metal plates. Samples were characterized by density measurements, X-ray diffraction (XRD), DSC and Raman spectroscopy.

\section{RESULTS AND DISCUSSION}

XRD measurements were performed on Bruker D8 Focus X-ray diffractometer using $\mathrm{Cu} \mathrm{K}_{\alpha}$ radiation $(\lambda=1.5406 \AA)$ in the $2 \theta$ range of 10 to $60^{\circ}$. XRD patterns do not show any sharp peaks, but broad hump from 25 to 30 degree which confirms the amorphous structure of all samples [Figure. 1].

Density of glasses was measured by Archimedes method using an electronic balance of sensitivity $10^{-4}$ g. Density of samples decreases from 6.282 to $5.101 \mathrm{~g}$ $\mathrm{cm}^{-3}$ as $\mathrm{B}_{2} \mathrm{O}_{3}$ content increases due to replacement heavier $\mathrm{TeO}_{2}(159.6 \mathrm{amu})$ by lighter $\mathrm{B}_{2} \mathrm{O}_{3}(69.62 \mathrm{amu})$ 


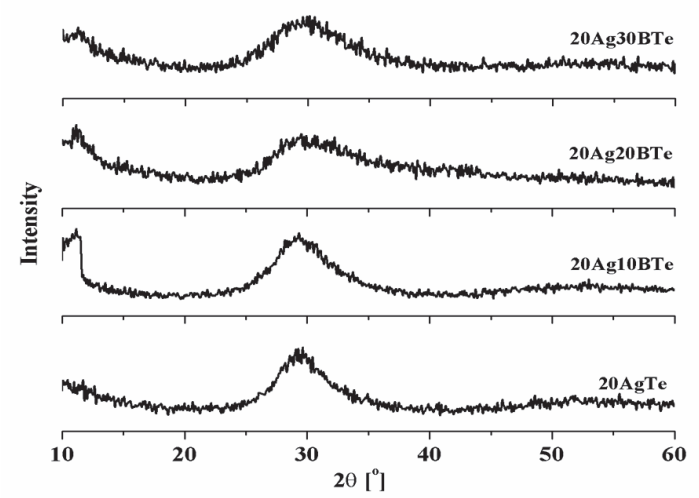

FIGURE 1. XRD patterns of $\mathrm{Ag}_{2} \mathrm{O}-\mathrm{B}_{2} \mathrm{O}_{3}-\mathrm{TeO}_{2}$ glasses.

[Table 1]. Both density and molar volume decreases on adding $\mathrm{B}_{2} \mathrm{O}_{3}$ in silver tellurite glass. This anomalous behavior has also been reported in other glass systems $[4,10]$. Variation of density and molar volume of $\mathrm{Ag}_{2} \mathrm{O}-\mathrm{B}_{2} \mathrm{O}_{3}-\mathrm{TeO}_{2}$ glasses with $\mathrm{B}_{2} \mathrm{O}_{3} \mathrm{~mol} \%$ is shown in Figure 2.

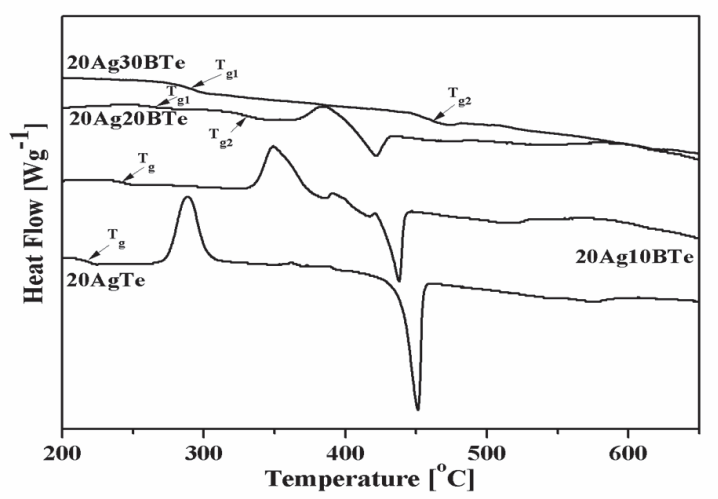

FIGURE 3. DSC patterns of $\mathrm{Ag}_{2} \mathrm{O}-\mathrm{B}_{2} \mathrm{O}_{3}-\mathrm{TeO}_{2}$ glasses.

on SETARAM SETSYS Evolution-1750 system in the temperature range of $200-650^{\circ} \mathrm{C}$ at a heating rate of $10^{\circ} \mathrm{C} / \mathrm{min}$, in air flow of $20 \mathrm{ml} / \mathrm{min}$.

DSC patterns of silver tellurite glasses are shown in

TABLE 1. Density, molar volume and DSC data for silver-borotellurite glasses.

\begin{tabular}{|c|c|c|c|c|c|c|c|c|c|}
\hline \multirow[t]{2}{*}{ Sample Code } & \multicolumn{3}{|c|}{$\begin{array}{c}\text { Composition } \\
\text { (mol.\%) }\end{array}$} & \multirow[t]{2}{*}{$\begin{array}{l}\text { Density (d) } \\
\left(\mathrm{g} \mathrm{cm}^{-3}\right)\end{array}$} & \multirow[t]{2}{*}{$\begin{array}{l}\text { Molar Volume }\left(V_{M}\right) \\
\left(\mathrm{cm}^{3} \mathrm{~mol}^{-1}\right)\end{array}$} & \multicolumn{2}{|c|}{$\begin{array}{c}\mathbf{T}_{\mathrm{g}} \\
\left({ }^{\circ} \mathrm{C}\right)\end{array}$} & \multirow[t]{2}{*}{$\begin{array}{r}\mathbf{T}_{\mathbf{c}} \\
\left({ }^{\circ} \mathrm{C}\right)\end{array}$} & \multirow[t]{2}{*}{$\begin{array}{l}T_{m} \\
\left({ }^{\circ} \mathrm{C}\right)\end{array}$} \\
\hline & $\mathrm{Ag}_{2} \mathrm{O}$ & $\mathrm{B}_{2} \mathrm{O}_{3}$ & $\mathrm{TeO}_{2}$ & & & $T_{g 1}$ & $T_{g 2}$ & & \\
\hline $20 \mathrm{AgTe}$ & 20 & - & 80 & 6.282 & 27.70 & 214 & - & 288 & 451 \\
\hline 20Ag10BTe & 20 & 10 & 70 & 5.973 & 27.63 & 240 & - & 349 & 438 \\
\hline 20Ag20BTe & 20 & 20 & 60 & 5.936 & 26.29 & 263 & 330 & 384 & 421 \\
\hline 20Ag30BTe & 20 & 30 & 50 & 5.101 & 28.83 & 289 & 461 & - & - \\
\hline
\end{tabular}

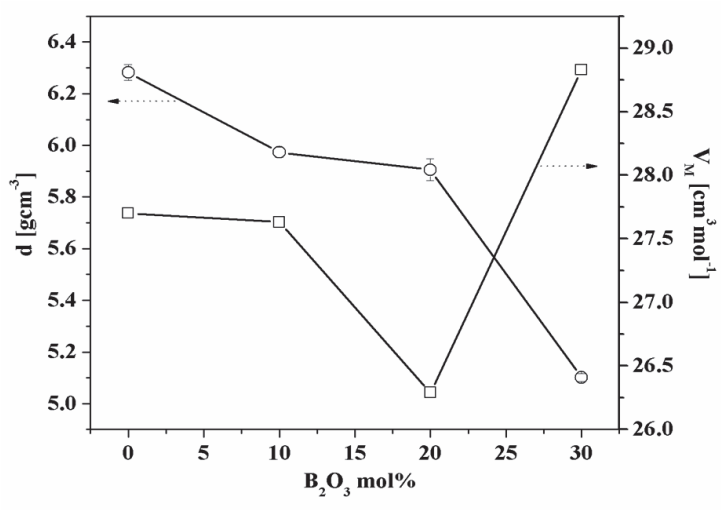

FIGURE 2. Variation of density and molar volume in $\mathrm{Ag}_{2} \mathrm{O}$ $\mathrm{B}_{2} \mathrm{O}_{3}-\mathrm{TeO}_{2}$ glasses with $\mathrm{B}_{2} \mathrm{O}_{3} \mathrm{~mol} \%$.

Thermal properties such as glass transition temperature (midpoint value, $\mathrm{T}_{\mathrm{g}}$ ), crystallization (peak point, $\mathrm{T}_{\mathrm{c}}$ ) and liquidus temperatures (peak point, $\mathrm{T}_{\mathrm{m}}$ ) were measured by DSC. These studies were performed
Figure 3. It is found that $\mathrm{T}_{\mathrm{g}}$ increases from $214{ }^{\circ} \mathrm{C}$ to $289^{\circ} \mathrm{C}$ with increase in $\mathrm{B}_{2} \mathrm{O}_{3} \mathrm{~mol} \%$ due to the greater bond enthalpy of B-O (804 $\left.\mathrm{kJ} \mathrm{mol}^{-1}\right)$ than Te-O (376 $\mathrm{kJ} \mathrm{mol}^{-1}$ ) and due to the formation of metal ion-oxygen bonds with terminal oxygens that increases the strength of glass network $[11,12]$. Glasses with 20 and 30-mol \% show double glass transitions in DSC scans [Figure. 3], which indicates phase separation. Sample with $30-\mathrm{mol}_{0} \mathrm{~B}_{2} \mathrm{O}_{3}$ does not show crystallization and melting peaks. Glass transition temperature characterizes the strength of the glass network. Values of glass transition, crystallization and liquidus temperatures are given in Table 1.

Short-range structure of glasses was studied by Raman spectroscopy. Raman spectra of glasses were recorded at room temperature using Renishaw InVia Raman Microscope. The excitation wavelength was $514.5 \mathrm{~nm}$. Figure 4 shows the Raman spectra of silver borotellurite glasses. Samples show two characteristic Raman bands in the wavenumber ranges: 400 to 530 
$\mathrm{cm}^{-1}$ and 550 to $820 \mathrm{~cm}^{-1}$. Strong peak at low wavenumbers of $\sim 55 \mathrm{~cm}^{-1}$ is the boson peak and is characteristic feature of glasses [9]. The Raman band in range 400 to $530 \mathrm{~cm}^{-1}$ is due to bending vibration of Te-O-Te linkages, similarly the band in range of 550 to $810 \mathrm{~cm}^{-1}$ is assigned to stretching vibrations of $\mathrm{TeO}_{4}$ tbp and stretching vibrations of $\mathrm{TeO}_{3}$ tp structural units $[5,8]$. The Raman spectra were deconvoluted with peaks centered at 461, 608,656,700 and $745 \mathrm{~cm}^{-1}$. The areas under the peaks were used to determine the Te-O coordination number by using following formula [12]:

$$
N_{T e-O}=3+\frac{A_{608}+A_{656}}{A_{608}+A_{656}+A_{700}+A_{745}}
$$

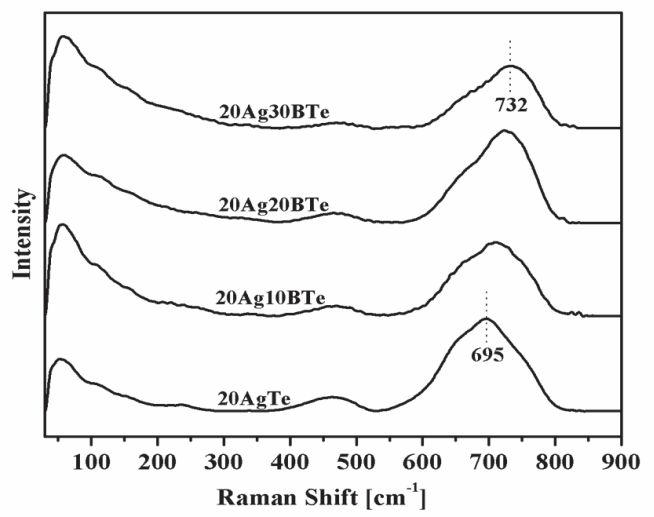

FIGURE 4. Raman spectra of $\mathrm{Ag}_{2} \mathrm{O}-\mathrm{B}_{2} \mathrm{O}_{3}-\mathrm{TeO}_{2}$ glasses.

The peak at $695 \mathrm{~cm}^{-1}$ shifts to $732 \mathrm{~cm}^{-1}$ and $\mathrm{N}_{\mathrm{Te}-\mathrm{O}}$ decreases from 3.42 to 3.18 with increase in $\mathrm{B}_{2} \mathrm{O}_{3}$ concentration [Figures 4-5 \& Table 2]. Decrease in $\mathrm{N}_{\mathrm{Te}-\mathrm{O}}$ is due to the transformation of $\mathrm{TeO}_{4}$ into $\mathrm{TeO}_{3}$ structural units on incorporating $\mathrm{B}_{2} \mathrm{O}_{3}$.

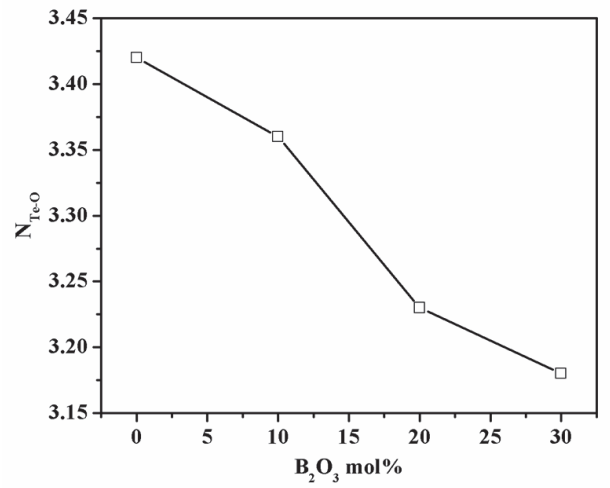

FIGURE 5. Variation of $\mathrm{N}_{\mathrm{Te}-\mathrm{O}}$ with $\mathrm{B}_{2} \mathrm{O}_{3} \mathrm{~mol} \%$ in $\mathrm{Ag}_{2} \mathrm{O}$ $\mathrm{B}_{2} \mathrm{O}_{3}-\mathrm{TeO}_{2}$ glasses.
TABLE 2. Te-O coordination number, $\mathrm{N}_{\mathrm{Te}-\mathrm{O}}$ in silver tellurite and borotellurite glasses.

\begin{tabular}{ccc}
\hline Sample code & $\begin{array}{c}\text { Raman peaks } \\
\text { area ratio }\end{array}$ & $\mathbf{N}_{\text {Te-o }}$ \\
\hline 20AgTe & 0.42 & 3.42 \\
20Ag10BTe & 0.36 & 3.36 \\
20Ag20BTe & 0.23 & 3.23 \\
20Ag30BTe & 0.18 & 3.18 \\
\hline
\end{tabular}

\section{CONCLUSIONS}

Silver borotellurite glasses were prepared and characterized by density, XRD, DSC and Raman spectroscopy. Density of glasses decreases from 6.282 to $5.101 \mathrm{gcm}^{-3}$ and glass transition temperature increases from $214^{\circ} \mathrm{C}$ to $289^{\circ} \mathrm{C}$ on adding $\mathrm{B}_{2} \mathrm{O}_{3}$ up to $30-\mathrm{mol} \%$. Increase in $\mathrm{T}_{\mathrm{g}}$ is due to the strengthening of glass network. Raman studies found $\mathrm{N}_{\mathrm{Te}-\mathrm{O}}$ decreases from 3.42 to 3.18 on adding $30-\mathrm{mol} \%$ of $\mathrm{B}_{2} \mathrm{O}_{3}$ in silver tellurite glasses due to increase in concentration of $\mathrm{TeO}_{3}$ units.

\section{REFERENCES}

1. D. Souri, Measurement 44, 717-721 (2011).

2. R. El-Mallawany, Materials Chemistry and Physics 63, 109-115 (2000).

3. G. Upender, V.G. Sathe and V.C. Mouli, Physica B: Condensed Matter 405, 1269-1273 (2010).

4. M.K. Halimah, W.M. Daud, H.A.A. Sidek, A.W. Zaidan and A.S. Zainal, Materials Science-Poland 28, (2010).

5. B.V.R. Chowdari and P.P. Kumari, Materials Research Bulletin 34, 327-342 (1999).

6. S.R. Bharadwaj and G. Chattopadhyay, Journal of solid state chemistry 80, 256-265 (1989).

7. E.R. Barney, A.C. Hannon, D. Holland, N. Umesaki, M. Tatsumisago, R.G. Orman and S. Feller, The Journal of Physical Chemistry Letters 4, 2312-2316 (2013).

8. V.O. Sokolov, V.G. Plotnichenko, V.V. Koltashev and I.A. Grishin, Journal of Non-Crystalline Solids 355, 239-251 (2009).

9. D. Dutta and A. Ghosh, The Journal of Chemical Physics 128, 044511 (2008).

10. V. Rajendran, N. Palanivelu, B.K. Chaudhuri and K. Goswami, Journal of Non-Crystalline Solids 320, 195-209 (2003).

11. A. Gulenko, O. Masson, A. Berghout, D. Hamani and P. Thomas, Physical Chemistry Chemical Physics 16, 14150-14160 (2014).

12. N. Kaur and A. Khanna, Journal of NonCrystalline Solids 404, 116-123 (2014). 